\title{
Written Manuscripts in Ancient Kipchak Language of 13-15th Centuries and their Research Problems in Kazakhstan
}

\author{
Kunduzay Aubakirova \\ Bayan Jubatova \\ Anar Mustafayeva \\ Rashid Mukhitdinov
}

Aigul Zhiyekbayeva

al-Farabi Kazakh National University, Almaty, Kazakhstan; Email: academic.uni@mail.ru

Doi:10.5901/mjss.2015.v6n5s1p575

\section{Abstract}

\begin{abstract}
To date there are many different hypotheses about the socio-ethnic background of Egyptian Mamluks. Lately, research has been taking place that only connects the ethnic origin of Mamluks who ruled the lands of Egypt and Syria during XIII-XV centuries and sultans of that era such as Baybars, Qalauin, Qaitabai to only a single present-day nation's history and that only connects the language of written medieval manuscripts of XIII-XV centuries, when Mamluks were in power, with only one present-day nation's language. In order to understand who were the Egyptian Mamluks and to clarify the ethnic composition of Kipchak and Circassian Mamluks attention should be paid to their language which is a component of the ethnic conception. And to figure out the language of the Mamluks who ruled Egypt and Syria during XIII-XV centuries a comprehensive study of the language of the manuscripts must be carried out. In our opinion, the ancient medieval manuscripts written in Kipchak language should be considered as a common heritage of all Turkic people. Taking into account, that language materials in ancient Kipchak language had been preserved in present day Kipchak language, we can say, that the written manuscripts in Mamluk-Kipchak language have a great role in research of social, ethnic, political-social, literary-cultural, total civilizational and linguistic histories of the modern Turkic people, particularly Kazakhs, Karakalpaks, Nogais, Tatars, Bashkirs, Qarays, Karachay-balkars, Kumyks, Crimean Tatars, Crimeans, Kyrgyz and people of the Altai of Kipchak group.
\end{abstract}

Keywords: Mamluks, written manuscripts, Arabic-Kipchak dictionaries, Kipchak language, Kazakhstan

\section{Introduction}

Many restoration programs on national history and research, preservation, renovation and efficient use of the ancient heritage and history, in depth studies of cultural relics of the history that were going to be forgotten were adopted after the independence of the Republic of Kazakhstan. The importance of the preservation of the national culture and spirituality is present in this XXI century where processes such as modernization and globalization which are a threat to national uniqueness and national identity. Therefore, "The concept of the formation of the historical consciousness of the Republic of Kazakhstan" which has aimed to preserve Kazakhstani society and the cultural values of the country, and reconstruction of cultural relics were adopted in 1998 by the initiative of the President of Kazakhstan N.A.Nazarbaev, and was published in 1995 by the theme of "National unity and the year of the nation's history". The state-run programs like "Cultural Heritage" from 2004-2006 that were adopted on January 13th, 2004, "People on the wave of history" in 2013 was also adopted.

The research works in history, archeology, ethnography and culture were conducted during 2004-2011 years, where the "Cultural Heritage" program had been implemented and the results of the project had obtained a great historical importance. If the "Cultural Heritage" strategic project revived and saved the national cultural and historical relics, then the program "People on the wave of history" was created, as a continuation of the main objective, to expand the horizon of the national history of Kazakhs and to form new historical outlook of the nation.

Within the confines of these programs many written manuscripts, relicts, books and archival documents in Arabic, Persian, Turkic, Shagatay, Kipchak and other languages which have historical importance to the cultural heritage of Kazakh people were brought from foreign archives and libraries to Kazakhstan. Particularly, there are plenty of data 
relating to the Kazakh lands during Kipchak era which is considered to be one of the important periods of Middle Ages history of Kazakhstan and Mamluk era which hold an essential place in Islamic civilization. Our cultural-historical relicts relating Kipchak culture and language in the Middle Ages were born on the other side of the Mediterranean sea approximately in XIII-XV centuries during Mamluk ruling. Even though nations of Kipchak union couldn't save their ancient written manuscripts of Otyrar, Atil, Bolghar in their native land, the Arabic world preserved cultural-literary heritages of Kipchaks up to current days.

A conclusive hypothesis hasn't been stated yet about the ethnic origin, culture and language of Egyptian Mamluks. Several issues relating history and culture of Kipchaks during Mamluk ruling were considered by Russian, foreign and Kazakh scholars. For instance, in the research work of B.Batyrshauly named "The relationship of Egyptian Mamluk State with Polovetsian steppes. XIII-XV centuries" (Batyrshauly, 2005), the relationship of Egyptian Mamluk State with Polovetsian steppes and with Iraqi State of Jalaiyr in XIV century were considered. Also in work of A.Alibekuly named "Turkic-Kipchak literature of Mamluk's ruling period" the formation, development of Turkic-Kipchak literature and its representatives and its poetic dimensions were studied (Alibekuly, 2008). At the same time, some issues relating to this topic were discussed in works of scholars like V.G.Tizengawzen, S.Lén-Paul, G.Weyl, M.Wilm, G.V.Vernadskiy, V.V. Bartold, B.E. Kumekov etc. The language features of written manuscripts in Mamluk-Kipchak language of Mamluk era were considered in number of works of scholars like A.Djaferogly, T.Houstma, A.Zayonchkovskiy, E.Nadjip, A.Chaykovskaya, A.Yunusov, E.I.Fazylov, S.M.Mutallibov, Z. B.Muhamedova, I.A.Rasulova, R.Ermers, G.R.Gaynutdinova and among Kazakh scholars: M.Majenova, A.Quryshjanov, T. Arynov, S.Duisenov, S.Boranbaev, E.Esbosynov, B.Suierqu. However, these research works weren't able to create a complete cultural and philological sketch of the matter using the volume of contained materials. Kipchak culture and language during the Mamluk rule requires in depth study from the point of anthropocentric paradigm.

\section{Research Methods}

During the study, the written manuscripts in Mamluk-Kipchak language which have originated during the rule of Mamluks (XIII-XIV century) and that were imported into Kazakhstan within the framework of above-mentioned state programs were determined and comparative-historical, comparative, classificational, analyzing, descriptional, presentational and etc. methods were used. Through comparative-historical, analyzing and classificational methods manuscripts in MamlukKipchak language were determined when, where and by whom were written and were classified by structure and content. Through comparative, analyzing and descriptional methods the foreign and domestic research works on the grammar works and Arabic-Kipchak dictionaries written in medieval literary Arabic language relating to Mamluk-Kipchak language were analyzed and unresolved issues up to the current days relating to the study of manuscripts in ancient Kipchak language were determined. The objects of this study are ancient medieval manuscripts written in Kipchak language and foreign and domestic research works on this manuscripts.

\section{Results}

At present time in Kazakhstan, there are many different hypotheses concerning the origin and ethnic composition of the Egyption Mamluks. Arabic, Russian and Western sources define Mamluks as warrior-slaves of Turkic Caucasian origin from medieval Egypt and who came to power by deposing the rulers of the Ayub dynasty in 1250 and then split into two dynasties. The Mamluk dynasty which ruled during 1250-1390 years was named as Bahri (Turkics, in essence of Kipchak family), and Mamluks who ruled during 1390-1517 years (natives of the Caucasus, Circassian) were called Burji. Thus, the ethnic composition of Mamluks consisted of Turks and Circassians. Western, Russian and Arabic researchers consider Caucasian Circassians separately from Kipchak Sultans from the ethnic point of view. But Turkish and Kazakh scholars argue that their separation into two dynasties is not related to their ethnic composition. In the past, Mamluks military exercises were held on the island ar-Rawdah by the Nile River thus it was named Bahri, and then the military training area of Mamluks under the rule of Qalawun was in the castle in the city of Cairo thus it was called Burji. Q.Begalin states that despite the fact of almost all of the people of the North Caucasus and Ukraine were called Circassians in Russian records of different historical periods, currently there is no other nation that has such a name except the Kazakhs who are the members of Little Juz and Alabugy Tatars. Scholar associates Circassians Mamluks with Sherkesh clan of Little Juz who are widespread in Western Kazakhstan, present day Atyrau and Ural regions (Begalin, 2012, 133).

Orientalist B.Batyrshauly tried to prove in his work the ethnic unity of Mamluks based on medieval Arabic written data which exemplify the ethnic, cultural, linguistic, anthroponimical, traditional, ritualistic features of Kipchak and 
Circassian Mamluks. Author came to conclusion that it is reasonable to directly connect the Circassians of Mamluk period with current Sherkesh clan which is the part of Little Juz of the Kazakh people and who have inhabited the western region of Kazakhstan since distant times (Batyrshauly, 2005).

It is necessary to consider the element of the language, which is the component of the concept of ethnicity in order to determine who were the Egyptian Mamluks in reality and to determine the ethnic composition of the Circassian Mamluks. And to resolve the language of Mamluks who ruled the lands of Egypt and Greater Syria during XIII-XV centuries, the language of the written manuscripts of that period should be comprehensively researched. The dictionaries and grammatical works in Mamluk-Kipchak language that were written during Mamluk's ruling have got a great importance. However, there are many scholars who studied such manuscripts written in ancient medieval language from the historical and comparative perspective and considered them as a heritage of only one nation. For example, the Uzbek scholar I.A. Fazylov in his research work "Starouzbekskiy yazyk. Horezmeyskie pamyatniki XIV veka" (Ancient Uzbek language. Monuments of Horezm of XIV century) (Bainazarov A., Bainazarova J., 2014), considers medieval works such as "Gulistan", "Muhabbatname", "Hosrau-Shyryn", and etc. as records written in ancient the Uzbek language. At the same time, the Turkmen scholar Z.B. Muhamedova studied dictionaries in the Mamluk-Kipchak language and connected them in her research work with the history of the Turkmen language (Z.B. Mukhamedova, 1969), G.R. Gainutdinova studied "Bulgatu-I-mushtaq" as a written relic of the Turkic-Tatar language and studied the phonetic, morphological and lexical features of the manuscript (Gainutdinova, 2005). Some Kazakh scholars individually considered the manuscripts in the Mamluk-Kipchak language in their works, and while comparing its linguistic materials with the modern Kazakh language, came to conclusion that these relics must be examined as manuscripts written in the ancient medieval Kazakh language. Kazakh scholar T.A. Arynov in his thesis, through comparing the dictionary of "At-tuhfa" with the modern Turkic languages, correlated the lexical material with present Kazakh language. After reviewing the lexicon of the dictionary, the scholar, reminds that $2.5-3 \%$ of words are borrowed words, $5 \%$ of words of above mentioned manuscript are in the Turkmen language, $15-20 \%$ are in Turkic languages of Kipchak language group, and 75-80 \% of words are in the Kazakh language (Arynova, p.79).

In recent times, there has been the phenomenon of correlating the ethnic origin of Mamluks, who ruled in lands of Egypt and Greater Syria in XIII-XV centuries and sultans of that period like Beybars, Qalawun and Qaitbay with the history of only one single nation, and correlating the language of those medieval manuscripts with one definite modern language. For solving problems in linguistics relating to the ethnic origin of Mamluks and Kipchak language of those periods, the manuscripts written in ancient Kipchak language must be entirely examined from anthropological actuality paradigm point of view. In our opinion, the ancient medieval manuscripts written in Kipchak Language should be considered not as a sole possession of only one nation, but as a common heritage of all Turkic people.

The state of Mamluks (1250-1517) was a country in which warrior-slaves ruled in the lands of Egypt and Greater Syria and they were of Turkic and Caucasian background. If we are to stop on the origin of the word "Mamluk", it was related to "white slaves", who played a major role in the history of Islam. This word in Arabic "malaka", is a participle of passive voice of verb that means "to own", "to rule". Word "Mamluk" initially had meaning "property owned by someone", "property which has an owner", then depending on the historical conditions of that time and the sphere of use acquired a second meaning - "white slave" (Abdulfattah, 1976, 1).

Concerning the origin of Mamluks, A. Quryshjanuly writes: "From ethnic composition point of view, Mamluks were representatives of different countries. Many cohorts of tribes, clans and people who were captured were always sold into slavery. Among them there were many valiant citizens of clans and nationalities from "Polovetsian" valley (Altai and the Dnieper, and further until Dniester and Danube rivers) at that time. Along with the slaves, there were also those who voluntarily joined Mamluk Guards (Kipchaks, Turks, Turkmens, Georgians, Slavs, Europeans and Caucasians etc.), but they collectively obeyed the central rule of Kipchak government and spoke one language - only in Kipchak language (officially)"(Quryshjanuly 2007, 17-18). Thus, A. Quryshjanuly came to conclusion, that Mamluks had been speaking in the Kipchak language, and highly appreciated the role of Kipchak language in the Egyptian society during the rule of Mamluks. The correspondence of Mamluk sultans with the kings of the Golden Horde in Arabic and Turkic-Kipchak languages and the dictionaries and grammatical works in the Arab-Kipchak languages written at that time can be used as backing of Scholar's words. Because Kipchak language during the rule of Mamluks had been widely used and its' influence was very strong, and we can notice it from preserved Turkism which assimilated into Arabic language. Medieval Arabic sources mention that the Mamluks who ruled in Egypt for nearly three centuries, spoke between themselves in Kipchak language. During Middle Ages, in Egypt and Greater Syria there was a great interest in the Kipchak language. As result literary, religious, grammatical, lexical, equine and military related written manuscripts were born in MamlukKipchak language (in Arabic sources it is used as Halis Turkic language). Study of such manuscripts in Mamluk-Kipchak language has a significant role within the wider research of social, ethnographic, political-social, literary-cultural, linguistic 
history of present Turkic people, particularly, of the people belonging to the Kipchak language group. The written manuscripts written in Mamluk-Kipchak language during XIII-XV centuries under the rule of Mamluk can be categorized as follows:

1) Dictionaries and grammatical works;

2) Religious works;

3) Works relating to the equine and military art;

4) Literary works.

\subsection{Study of dictionaries and grammatical works in Mamluk-Kipchak language in Kazakhstan}

1) Kitab al-idrak lilisani al-atrak

The written manuscript "Kitab al-idrak lilisani al-atrak" ("Explanation book about the Turkic language") was written on December 18, 1312 in Cairo. The author of the work, Abu Xayyan, wrote his works which were devoted to the learners of Turkic language, like "Kitab Hahui---mulk fi nahui-t-turk" ("Book of bright ownership in Turkic grammar"), "Kitab al-auual fi lisani-t-turk" ("The first book in Turkic language") and "Kitab al-idrak lilisani al-atrak" ("Written explanation book about the Turkic language"). However, only the last of them has reached us. The original work wasn't preserved; all we have are the only different three copies of this work. Its first version has been kept in Bayazid National Library, the second in the Library of Istanbul University and the third version in the Darul-Kutub Library in Cairo. The manuscript was first published in 1891 in Istanbul. The compilation consists of two parts: 1) The Turkic-Arabic dictionary (consists of 3500 nouns and verbs); 2) the chapter of grammar: phonetics and morphology (consisting of 78 parts) (Mazhenova, 1969).

The dictionary "Kitab al-Idrak" was considered in works of scholars like L.Bauvat, R.Ermers, A. Jaferulu, M.Ozietgin, M.Majenova, I.A.Rasulova, E.Z.Esbosynov and etc. and was translated into several languages. As well as the language materials of written manuscript were extended into application by researchers like A.Quryshjanov, Z.B.Muhamedova, A.I.Chaykovskaya, S.R.Boranbaev, B.M.Suierqul and etc. R.Ermers made a comparative analysis to about ten manuscripts written in the ancient medieval Kipchak language in his research work, and translated the dictionary "Kitabu al-Idrak" into English. Kazakh scholar M. Mazhenova showed phonetic, grammatical and lexical features of the medieval manuscript in her research work "Abu Xayyan - issledovatel kipchakskogo yazyka" ("Abu Xayyan - the researcher of Kipchak language"). The author came to the following conclusion by comparing the lexical base of the manuscript with the present Kazakh language: 875 words in manuscript, that is, the 36.5 per cent of the words fully comply with vocabulary of the Kazakh language from the phonetic and semantic point of view, and 800 words, that is, the 33.5 per cent of words had some phonetic changes. The rest of the words of above-mentioned manuscript are common for the present Turkic languages of the Oguz-Turkmen group. Kazakh scholar E. Esbosynov fully wrote about the lexical and grammatical features of the "Kitab al-Idrak" in his work named" The lexical and grammatical features of ancient Kipchak language" (according to Abu Xayyan's work, XIY c.), and proved that lexical and morphological structure of nouns in the language of manuscript are very closely tied to the modern Kazakh language.

2) Kitab madjmu' tardjuman turki ua a'djami ua muguli ua farsi

Manuscript "Kitab madjmu' tardjuman turki ua a'djami ua muguli ua farsi" was written in order to teach the Arabs the Turkic language in Egypt. The original copy of this work has been kept in Academic Library of Leiden in the Netherlands under the number 517 (Houstma, 1894). This collection which consists of 76-page is written in red and black ink. The first part which consists of 63 pages is an Arabic-Turkic dictionary and grammar related, and the second part which consists of 13 pages is Mongolian-Persian dictionary. The Arabic-Turkish part of this work consists of four chapters. If in the first two chapters include series of nouns and verbs are given, the last two chapters are related to grammar. The author tells that he knows several Turkic languages, including pure Turkish language or the Turkic-Kipchak language "التركية , and Turkmen language "التفجاقية" (Quryshzhanov, 1970, 17). Turkish scholar A. A.Inan associated the presence of several languages (Arabic, Persian, Mongol) in the same dictionary with Mongol rule in Iran and the rule of Mamluk-Kipchaks in the lands of Egypt and The Greater Syria [Inan, 1953, 60]. The Dutch orientalist Martin Teodar Houstma translated it into German and published the work in 1894. This research work of scholar relating to the written manuscript of the Turkic-Kipchak language became a valuable work in the field of the Turkology. Polish researcher A. Zajaczkowski stated concerning above-mentioned "Tardjuman turki" manuscript, that it is one of the written manuscripts of Mamluk state or is a member of antique dictionaries in Arabic-Turkic (Kipchak) language "( Zajaczkowski, 1961). The scholar suggests improving the translated and transcription version in the German-language of M.T. Houstma who incorporated this historical heritage for the first time into scholarly usage.

The Uzbek scholar A.Yunusov considered above mentioned dictionary's structural, morphological, lexical-semantic points in his research work named "Tardjuman turki ua ajami ua mugali: Morfologiya, leksika, slovar, perevod 
(Morphology, lexicon, dictionary, translation)" and translated the dictionary. In 1970, Kazakh scholar A. Quryshjanuly made a comprehensive study of above-mentioned dictionary and translated into Russian while being guided by M.T. Houstma's research work in his work named "Issledovanie po leksike starokypchakskogo pismennogo pamiyatnika XIII v. Turksko-arabskogo slovariya" ("Research of lexicon of manuscript written in ancient Kipchak language of Turkic-Arabic Dictionary of XIII c.").

3) Kitab at-tuhfa az-zakiya fil-lugati at-turkiya

"Kitab at-tuhfa az-zakiya fil-lugati at-turkiya" ("The special gift written in the Turkic language") - was the first manuscript written concerning the language of Mamluk Kipchak in Arabic language and was based on Arabic grammar model. The author and written date are unknown. There is only a single exemplar of the manuscript which consists of 91 sheets (182 pages) and should have been written in XIV century in Egypt. It has been preserved in Validdin Efendi Library of Bayazit Mosque in Istanbul (Toparly, 2000). It stands on the third place after M. Kashgari's and A.Hayyan's works based on it's historical-cultural and scholarly value. The name of the famous philologist of XIV century Abu Hayyan was mentioned in the work, apparently the author was familiar with his works. T.H.Kun published a special article concerning this manuscript in 1940. The original was published in 1942, in Hungary. This work is known in Western Europe since 1922. B.Atalay translated it into Turkish and published it in 1945. In 1967, the Polish scholar A.Dwbanskiy conducted research works on its language. In 1968, S.S. Mutallibov translated it into Uzbek language and published it. In 1978 it was translated into Russian (E.Fazylov, M.Ziyaev). (Quryshjanuly, 1998, pp. 172-171.). Professor A. Quryshjanulu was first among Kazakh scholars who mentioned about "At-tuhfa" and its translations. T.Arynov through comparison and comprehensive analysis of vocabularies of manuscript with other medieval works and modern Turkic languages proved that almost all of the lexical materials are in accordance with the words of the modern Kazakh language in his work named "Leksiko-semanticheskie I stilisticheskie osobennosti yazyka staroKipchakskogo pamiyatnika "Kitab at-tuhfa azzakiya fil-luga-at-turkiya" ("Lexical-semantic and stylistic features of the ancient Kipchak language of manuscript "Kitab attuhfa az-zakiya fil-luga at-turkiya"), and made up for the first time Kipchak-Kazakh dictionary. T.Arynov analyzed all vocabulary of "At-tuhfa" and determined the proportion of the Turkic (97.5\%), Arabic (0.4\%), Persian (2.1\%) words in it (Suyerqul, 1999). At the same time B. Suyerqul determined the morphological structure of the manuscript and fully researched verb forms in his thesis named " The verb categories in language of the manuscript "At-tuhfa".

4) Al-qauanin al-kulliya lidabt al-lugati turkiya

"Al-qauanin al-kulliya lidabt al-lugati turkiya" ("Collection of full set of standard rules of Turkic language") is work written in medieval classical Arabic language according to the Arabic alphabet and grammar concerning the specifics of Kipchak language at the beginning of the XV century in Cairo. The author and written date are unknown. Only one exemplar of this work has been preserved in Shahid Ali Pasha department of Suleymaniya library in Istanbul (Kun, 2013, 37). In 1928, the original manuscript was published by Mu'allim Rif'at Bilge in Istanbul, and in 1937 it was republished by Sh.Telegdi in Budapest. In Kazakhstan, S.Duysenov studied structural system, writing purpose, method of formation of language materials and phonetic features of "Al-qauanin" manuscript in his work named "Al-qauanin al-kulliya lidabt allugati turkiya - Collection of full set of standard rules of Turkic language (its content, graphics, spelling, phonetics)". The author fully researched the phonetic side of the manuscript and stated that the manuscript still needs to be studied (Duissenov S., 1995).

5) Kitab ad-durrat al-mudiya fi--Iugati turkiya ual-Kamal

"Kitab ad-durrat al-mudiya fi---lugati turkiya ual-Kamal" ("Bright pearl of the Turkic language and thoroughly written book") was an Arabic dictionary written in order to facilitate the learning of classical Kipchak language in countries of Egypt and Greater Syria during XIV century which was the state of Mamluk Kipchaks. The work is also called "Tarjuman al-luga at-turkiya" ("Translation dictionary of Turkic language") and "At-tarjumani at-turkiya" ("Turkic translation") in the manuscript. International Turkic scholar considered that this work "hadn't reached us" (B.Atalay), "had disappeared" (O.Pritsak). In 1963, the famous Pole Turkologyst A. Zajaczkowski found a manuscript of this dictionary in the famous library of Lorenzo de Medici in Florence, and published its translation in French (Warsaw, 1965-1969 y.). Its volume consists of 24 sheets, on the two pages of every sheet there are lists of words in Arabic-Kipchak. The lexical materials were separated into 24 chapters according to the semantic classification of Arabic words. The author of this dictionary and written date are unknown. Scholars such as K.D.Taujanova, A.Quryshjanov gave information about this manuscript for the first time in Kazakhstan (A.Quryshjanov, 1998. pp 170-171).

6) Kitab al-Bulgati al-mushtaq ua fil-lugati at-turk ua-I-qibdjaq

The author of the work which consists of 88 pages named "Kitab al-Bulgati al-mushtaq ua fil-lugati at-turk ua-lqibdjaq" was Jamal ad-Din Abu Muhammad Abdullah At-Turk. It was determined that this grammatical work written in Arabic-Kipchak language had been compiled in the Greater Syria not later than 1451. Only one version of the work had been preserved in the National Library of Paris. G.R. Gainutdinova illustrated to us the structural, phonetic and 
morphological features of the manuscript in her work named "Istoriko-lingvisticheskiy analiz turko-tatarskogo pismennogo pamyatnika XIV v. Jamal ad-Din at-Turki "Kitab bulgat al-mushtaq ua fi lugat at-turk ua-I-qifchaq" ("Historical-linguistical analysis of written Turkic-Tatar manuscript of XIV c. of Jamal ad-Din At-Turki "Kitab al-Bulgati al-mushtaq ua fil-lugati atturk ua-I-qibdjaq"). Sh. Fayzullaeva studied the grammatical and lexical features of this manuscript and made its translation.

Kazakh scholar Boranbayev S. in 2000, wrote his master's thesis under the supervision of A. Quryshjanov called "Eski qypshaq tilindegi esimderdi salystyrmaly-tarihi turgydan zertteu ("arabsha-qypshaqsha sozdik" boiynsha, XIV g.)" ("The study of names in ancient Kipchak language from the comparative-historical point view (according to the "ArabicKipchak dictionary", XIV c.)". The researcher conducted a comprehensive study of the words in "Arabic-Kipchak" dictionary from the phonetic, morphological and semantic point of view in his work, and sorted the words to semantic groups.

\section{Discussion}

XIII-XV centuries were an important period in the history of the development of the Kipchak language. During this period, the Kipchak language formed in three different regions, in different historical-social conditions, which were: the language of Golden Horde Kipchak s, the language of Kipchaks of the European steppe and the language of Egyptian Kipchaks. Many researchers state that the role of communicational language of Egyptian Mamluks had played the western Kipchak language. You can see in such dictionaries as "Kitab al-idrak", "Kitab at-tuhfa", "Al-qauanin" compiled at that time, that the Turkic language was the language of the army and public administration and language of the authorities. Many scholars by comparatively studying the manuscripts written in Mamluk-Kipchak language and heritage of Golden Horde in Kipchak language, unanimously state that there is only Kipchak language on the basis of the language of people in Golden Horde and Egyptian Mamluks, who had been living in different regions, during the rule of Mamluks, that means, there was only one single language of the nation. The ancient manuscripts in Kipchak language were written for a specific purpose, that means, that they were written in order to describe the ancient Kipchak language in a comprehensive way and from the lexical, morphological, differentiational and semantic points of view. The appearance of such works and its extension should have occurred from needs relating to political, public-social and cultural life of that era. In the third page of the collection "Al-qauanin" the author stated: "I'm neither Turkic, nor one of the Turkic offspring, I even hadn't been ever in their countries. I rely on what I heard from them, when I had good communication with them and when I was with them"(Recep, 1999, pp 240). And the author of famous "Kitab al-Idrak" Abu Hayyan stated about his way of writing of his work like following: "I wrote down the words from people who know the language gradually. I put them in order by myself. I hadn't taken principles written about Grammar from another work, I have written through my thought concepts "(kitab alidrak). We can see from following state of "At-tuhfa's" author: "I wrote this work in Kipchak language, because the most widely used language - Kipchak language. I didn't use Turkmen language, but I had been given some examples from it when it was very necessary, in these cases I had just apologized. Faith and hope are from God", that Kipchak language was widely used (At-tuhfa). Here, we can surely say that representatives of various Turkic people, who joined Egyptian Mamluks, brought there their own languages too. Also medieval Arabic sources stated that many Castle Servants were interested in learning Turkic-Kipchak language according to the requirements of that time in order to catch the attention of Turkic rulers. For example, the grand imam of a large mosque Sheihuni had spoken fluently in the Kipchak language due to the close relationship with emirs. Historian al-Aini knew Kipchak language very well too. He had translated historical books written in Arabic into Mamluk-Kipchak language for Sultan, and had explained them. Sultans of Egypt collected scholars in the castle in order to teach the Kipchak language during the Mamluk's rule (Al-Holi, 1962, 31). As evidence for this we can mention manuscripts compiled in Mamluk-Kipchak language under the order of above-mentioned sultans. For example, the author of "Al-qauanin" wrote his work as response especially to the questions of his teacher Mahmoud Saydulad Adnan and his teacher's friends about specificity of Turkic language. "I answered their questions, their requirements are relevant. I wrote this powerful work, it is very useful to others (Al-qauanin 3, 10-13). I have fulfilled nazir's will", thus, he states for more information. Here the author's nazir should mean the senior manager (Duissenov S., 1995). From this following is stated "The collection of rules of Turkic language by the Allah's most powerful forces made for the benefit of translators. I have called it "The full standard collection of rules of the Turkic language" (Duissenov S., 1995) in above mentioned manuscript we come to conclusion, that the purpose of writing such books and dictionaries for translators is to make acquainted the Arabs, the Berbers, the Copts, the Bedouins, etc. and the representatives of the local population, who had inhabited Egypt and the Greater Syria with the language of Mamluks; witch was the Kipchak language in Egypt and Greater Syria.

During the study of language materials of manuscripts in Mamluk-Kipchak language, there can be found many 
words such dombra (national musical instrument of Kazakh people), tunlik (the felt cover on the top of yurt), keli (a morter), keski (cutting tool), surgi (jack-plane), zhailyau (summer pasture), kumys, qurt (a kashk), airan (sour milk), sur et (smoked meat), that describe the way of life, which are not natural for these regions, but appropriate only to Kipchak culture. For determination the role of Kipchak culture and Kipchak language in Egypt and in the Greater Syria, as we stated above, the manuscripts written in ancient Kipchak language, which is a common heritage of all Turkic people mustn't be limited with research from only phonetic, morphological and structural features' point of view, but its lexical materials should be used as an invaluable source about history, culture, religion and language of that society.

\section{Conclusion}

During the analysis of research works relating to written manuscripts in Mamluk-Kipchak language, it was determined, that medieval manuscripts mostly had been comparatively studied with only modern Turkic languages from phonetic, morphological and structural points of view. The accordance of language of manuscripts in ancient Kipchak language with lexical basis of modern Turkic languages (Kazakh, Uzbek, Tatar, Turkmen, etc.) were determined in such historicalcomparative studies. It can be found, that some scholars consider such ancient medieval manuscripts written in Kipchak language like a heritage of only one, single nation. In our opinion, the ancient medieval manuscripts written in Kipchak language should be considered as a common heritage of all Turkic people. Taking into account, that language materials in ancient Kipchak language had been preserved in present day Kipchak language, we can say, that the written manuscripts in Mamluk-Kipchak language have a great role in research of social, ethnic, political-social, literary-cultural, total civilizational and linguistic histories of the modern Turkic people, particularly Kazakhs, Karakalpaks, Nogais, Tatars, Bashkirs, Qarays, Karachay-balkars, Kumyks, Crimean Tatars, Crimeans, Kyrgyz and people of the Altai of Kipchak group.

\section{References}

Batyrshauly B.S. (2005). Mysyr mamluk memleketinin Deshti-Kipchakpen baylanystary. XIII-XV gasyrlar. Almaty: Ekonomika.

Alibekuly A. (2008). Mamlukter biligi kezenindegi turki-Kipchak adebieti. Almaty: Arda.

Amin al-Huli (1964). Syilat beina an-nil ua al-vulga. Moskva: Izdatelstvo vsotochnoi literatury.

Komekov, B.E. (1987). Arabskie I persidskie istochniki po istorii kipchakov VIII-XIV vv. Nauchno-analiticheskii obzor. Almaty: Akademiya Nauk Kaz SSR.

Said Abdulfattah (1967). Al-asyr al-mamalik fi mysyr ua ash-sham. Al-qahira: an-Nashir.

Quryshanuly A. (2007). Mamluk qypshaqtarynyn tilinde jazylgan bir eskertkish jaiynda (algash habar esebinde). Kone turk eskertkishteri tarihy konferensiyalar materialdary. Turkistan.

Aidarov G., Quryshjanov A., Tomanova M. (1971). Kone turk jazba eskertkishterini tili. Almaty:Mektep.

Hafizbek (1995). Kitabu fathu Mysyr al-hadis. Qahira: Maktabatu madbuli.

Majenova M. (1969). Abu Hayyan - issledovatel kipchakskoga yazyka. Aforef. Almaty.

Houtsma M. (1894). Th. Ein türkisch-arabisches Glossar. Leiden.

Kuryshjanov A. (1970). Yazyk starokypchakskih pismennyh pamyatnikov XIII-XIY v. Almaty: Nauka.

Inan. A. (1953). XIII-XIV yuzyillarda Misirda oguz-turkmen ve kipchak lehceleri ve "Halis turkche". Ankara: TDAYB.

Quryshjanuly A. (1998). Kitab at-tuhfa az-zakiya fil-lugati at-turkiya. In E. Aryn (Ed.), Encyclopedia of The Kazakh language (Vol. 1, pp. 172-173). Almaty: «IDK-TIPO». P.- 508 б. 172-1716б.

Recep Toparly, Sadi Gogenli, Nevzat H (2000). Yanyk Kitabu Mejmu-I Terjumani Turki ua Ajami ua Mugali Ankara: Turk dili kurumu.

Halasy Kun, Hayriye Gul, Musa Salan (2013). Memluk kipchak dil arashtyrmalary ve Istanbuldaki el yazmalary. Dil arashtyrmalary, \#13.

Quryshjanuly A. (1998). Kitab ad-Durrat al-muddiya fil-lugati at-turkiya ual-kamal. In E. Aryn (Ed.), Encyclopedia of The Kazakh language (Vol. 1, pp. 170-171). Almaty: «IDK-TIPO».

Begalin Q. (2012). Mamluki. Moskva.

Duisenov S. (1995). Al-qauanin al-kulliya lidabti--lugati-t-turkiyati "Collection of full set of standard rules of Turkic language". Disser. Almaty.

Qasim Abdu Qasim (1998). 'Asr Salatin al-mamalik at-tarih as-siyasi ua al-ijtima'i. al-Qahira: Ayn.

Baynazarov A., Baynazarova Zh. (2014). Kypchak dictionaries and lexicography studies in Kazakhstan between thw $18^{\text {th }}$ and $20^{\text {th }}$ centuries. Bilig, 71, 81-92.

Mukhamedova Z.B. (1969). issledovanie po istorii turkmenskogo yazyka XI-XIV v. (po dannym araboyazychnyh filologicheskih sochinenii. Disser. Moskva.

Gainutdinova G.R. (2005). Istoriko-lingvisticheskii analiz turko-tatarskogo pismennogo pamyatnika XIV veka Jamal ad-Din at-turkii Kitab bulgat al-mushtaq. Kazan.

Arynov T.A. (1983). leksiko-semanticheskie I stilisticheskie osobennosti yazyka "kitab at-tuhfa az-zakiya fil-luga at-turkiya". Almaty.

Suerqul B. (1999). At-tuhfa eskertkishi (XIV g.) tilindegi etistik kategoriyalary: tarihy, salystyrmaly taldau. Almaty. 